Research Article

\title{
The Herd Behavior on Peer-To-Peer Online Lending Markets: Evidence from China
}

\author{
Rong Liu (i), Ningning Chen (D), and Yuelei Li \\ College of Management and Economics, Tianjin University, Tianjin 300072, China \\ Correspondence should be addressed to Rong Liu; lrong@tju.edu.cn and Ningning Chen; maria19940727@163.com
}

Received 15 October 2020; Revised 9 February 2021; Accepted 23 March 2021; Published 7 April 2021

Academic Editor: Seenith Sivasundaram

Copyright (c) 2021 Rong Liu et al. This is an open access article distributed under the Creative Commons Attribution License, which permits unrestricted use, distribution, and reproduction in any medium, provided the original work is properly cited.

Based on the transaction data and related borrowers' characteristics of Renrendai.com, this study conducts an empirical study on the influencing factors of the investor's herd behavior and rationality of herd behavior on a Chinese online lending platform. We mainly find that investors' herd behavior exists significantly on Renrendai.com; there is an "inverted U-shaped" relationship between the number of bids and the herd behavior of investors. When the number of bids exceeds a certain amount, the time required for the order to obtain another bid will be prolonged, and the investors' herd behavior will be slowed down; herd behavior on Renrendai.com in Chinese market is a partly rational pursuit, but irrational in general.

\section{Introduction}

Internet Finance (ITFIN), the dynamic integration of Internet technology and finance, implements its function by a financial service system created by cloud computing and big data, which shows a significant difference with the traditional finance industry. By June 2019, the number of online investment users had reached 170 million, accounting for 19.9\% of Chinese Internet users [1]. After nearly a decade of rapid development, the $\mathrm{P} 2 \mathrm{P}$ online lending platform has become an important supplement to traditional financial lending industry. These figures clearly show that the research on the P2P platform has become an important part of financial market.

Traditional financial institutions do not need to act as the intermediaries between lenders and borrowers. Compared with the traditional financial lending market, the $\mathrm{P} 2 \mathrm{P}$ online lending industry has three main characteristics in a typical lending process: Firstly, in online lending, borrowers get their money from many investors, which disperses the default risk of investors to a certain extent. Secondly, online lending provides a platform for investors on which they can check borrowers' private and loan information, besides invest behaviors of other investors. Through observation of the abovementioned information, investors then may make their own decisions. Thirdly, information asymmetry occurs between investors and borrowers, lacking related expert domain knowledge to judge a borrower's credit level and the probability of default, and investors can only use published information about borrowers and behavior of other investors. Some research has addressed such issues; for example, Freedman and Jin found the P2P online lending market Prosper has more significant problems of adverse selection and information asymmetry [2]. Consequently, the abovementioned characteristics of P2P online lending may lead to investors' behavior on the platform being easily influenced by other investors. In order to ensure the success of listing they invest in, investors may invest in a relatively popular listing, which leads to herd behavior among investors.

Herd behavior is initially a phenomenon in zoology in which groups of animals (sheep, cattle, etc.) move together to forage or seek habitat. This phenomenon was later applied in human sociology to describe the concerted action and thinking of people. In the finance field, herd behavior mainly refers to the imitation behavior of investors in the financial market who ignore their own information and follow the decisions of most people in the market. Many scholars in the finance field have given the concept and definition of herd behavior from different research perspectives [3-6]. Others also examine herd behavior of investors [7] and borrowers 
[8] at the platform level in the P2P market. Recent studies conduct empirical analysis on the relationship between herd behavior and other investors' emotion [9]. From the perspective of investor decision-making rationality, herd behavior can be divided into rational herding and irrational herding. Rational herd behavior refers to the behavior that investors rationally imitate and follow the decisions of other investors under the circumstance of information asymmetry from the perspective of profit making. Irrational herd behavior refers to the investors blindly following the decisions of other investors in the investment process. Several studies have been undertaken on the decision-making process of herd behavior $[10,11]$. The herd behavior often stems from the "sense of belonging" of individuals to the group, such as feeling secure when they make the same decision with the group, or individual investors directly choose to follow institutional investors' decisions due to the consideration of opportunity cost and information acquisition ability when making investment decisions. However, whether the herd behavior of investors in the Chinese P2P platform is rational is still a controversial issue. In this paper, we explore the existence and rationality of herd behavior and tries to explore the factors influencing herd behavior.

Our empirical analysis proceeds as follows: first, we explore whether the herd behavior exists in Chinese market and the relationship between the education level of borrowers and other related factors and herd behavior of lenders; second, we identify whether the herd behavior is rational. This study contributes to the current literature in two ways: first, we use a new proxy, the time it takes for an order to receive the next bid, to identify the herd behavior, which can reflect the herd behavior better; third, we study the rationality of herd behavior not only from the perspective of repayment performance but also from the perspective of the decision-making process of investors.

This study is organized as follows: Section 2 reviews the literature in herd behavior and P2P online lending market. Section 3 introduces data, variables, and methodology. Section 4 presents the empirical results. The conclusions and future research directions are summarized in Section 5.

\section{Related Literature and Hypothesis}

2.1. Whether There Is Herd Behavior. When an investor makes decisions in the $\mathrm{P} 2 \mathrm{P}$ online lending market, there is some information he or she may take into consideration. The first kind of information is the borrower's and order's information, some of which are not verified. The second kind of information is the hidden information obtained by an investor through observing the behavior of previous investors. If an investor is an expert with judging ability, and he can make decisions independently; otherwise, the behavior of the "pioneer" can affect investors' decision making significantly. Under the circumstance, investors may ignore their own intelligence and imitate the behavior of others. Moreover, the rule of the $\mathrm{P} 2 \mathrm{P}$ online lending market states only when the number of bidamount meets the ask of the order can it be completed. The abovementioned terms lead to the result that orders that have received partial bids are more likely to succeed than those that have not received any bids in the same period. If an investor bids for an order that is not fully completed finally, the money invested will be returned to their account, and they will not receive interest income in a period of time and will have to find other orders to bid again. Therefore, fail to bid an order will cause the opportunity cost (loss of interest income) and additional search costs (time lost to search for other orders); investors may be more willing to bid orders that have been partially bided in order to reduce the cost, which may lead to investors rushing to bid some order, and then, a herd behavior of investors is engendered. Studies on the herding behavior on the P2P lending platform are plentiful. Krumme and Herrero [12] discovered the herd behavior exists on Prosper, an online lending platform. Similar research is conducted by Herzenstein et al. [13]. Berkovich [14] made further research considering the cost of bidding; investors are more willing to invest in orders that have been or will be filled, which also proves the existence of herd behavior on Prosper. Others have also been undertaken on trend of herd behavior. Based on Popfunding, an online lending platform, the borrowers on which are mainly with low credit rating, Lee and Lee [15] proved the existence of herd behavior and the effect diminished with the increase of financing proportion. Yum et al. [16] found that the herd behavior of investors in Popfunding was based on information asymmetry. Not until investors had enough information to analyze and make decisions do they stop imitating others. By analyzing the data of Chinese Renrendai platform, Liao et al. [17] found that investors on the platform had a significant herding behavior, and with the increase of order completion, herd behavior marginally decreased. Moreover, the study also verified that herding behavior had a significant relationship with the information asymmetry of the platform. Li [18], Li [19], Lv [20], and other scholars have also proved the existence of herd behavior in Chinese online loan market.

Existing research on the existence of herd behavior of investors on the P2P lending market is mainly carried out from the perspective of the influence of the number of bids in the current period to the number of bids in the future or using the average time interval to measure the herd behavior. Most of the research uses the data from the unit of listings or a relative long time period, which cannot fully reflect the chasing behavior of investors. This study uses the time spent for the next bid to verify the existence of investors' herd behavior, which is more meticulous and in accordance with the premise that herd behavior decision making happens orderly. Based on the abovementioned literature, we raise the first hypothesis:

$\mathrm{H1}$ : Controlling the information of the borrower and the order, the higher the number of bids received by the order is, the faster the next bid will be obtained; that is, herd behavior exists in the Renrendai P2P online lending market.

In the study of Lee and Lee [15], the number of bids had a positive effect on herding behavior, but this effect decreased with the increase in the number of bids gradually; that is to say, the herding behavior of investors presented a trend of diminishing marginally with the increase of bids. For example, if there are two orders with the same loan amount 
and the fundraising ratio of both orders is $50 \%$, while order A currently has 20 bids and order B has 5, it is obvious that the average bid amount of order $B$ is much larger than that of order A. If an investor makes a decision choice with an imitation strategy, he will not invest in order A by simply comparing the number of bids received for the two orders, but invest in order $B$ by considering the potential risks of order A, which means order A may lose the trust of investors due to the large number of bids it has received. Therefore, if there are too many bids an order has received, investors' herd behavior may slow down to some extent. It may take more time for the order to get the next bid. The speed of order completion also slows down consequently. That is to say, there is an inverted U-shaped relationship between investors' herd behavior and the number of bids in the P2P online lending market. Based on the abovementioned analysis, hypothesis 2 is proposed.

H2: In the Renrendai P2P online lending market, the strength of herding behavior changes with the bidding state and herding behavior, and the number of bids an order has received has an "inverted U-shaped" relationship; when the number of bids is too large, investors' trust may decrease, and then, the order needs more time to obtain the next bid.

\subsection{Is the Herd Behavior Rational? From the perspective of} the rationality of herd behavior, herd behavior can be divided into rational herd behavior and irrational herd behavior. Rational herd behavior of investors can maximize their investment, which means investors can benefit from imitating others' investment decisions. On the contrary, irrational herd behavior is the blind herd behavior of investors. Studies on whether herd behavior in the current P2P lending platform is rational are plentiful. Using data of Prosper, Zhang and Liu [21] found that investors' herd behavior is rational after controlling unobserved heterogeneity and payoff externalities, while Luo and Lin [22] measured the rationality of herd by the potential loss benefit and found herd behavior is irrational on Prosper. Chen et al. [23] made an empirical analysis on the data of China's Paipaidai platform and found that investors in Paipaidai showed obvious herding behavior, which was irrational because investors' herding behavior did not have a positive impact on the repayment performance of orders. Zeng Jianghong and Yang Shuai [24] found that potential lenders would comprehensively consider the characteristics of the loan target and the behavior of previous lenders when making decisions, which is a manifestation of rational herd behavior. As to the definition of whether the behavior of investors is rational, Herzenstein et al. [13] use the impact of herd behavior on the reimbursement to define the rational degree of herd behavior, which means investors' rational herd behavior can reduce the loan default rates. If there is no positive relationship between herding behavior and repayment performance, investors' herd behavior will not bring benefits for themselves, and then, the herd behavior is irrational.

There is still no unanimous conclusion about whether the herd behavior in the Chinese online lending platform is rational. We follow the work of Herzenstein [13] to measure the rationality of the herd and consider the decision process of lenders and conduct the third hypothesis.

H3: Herd behavior of investors can reduce the probability of default in the Renrendai P2P online lending market.

\section{Data, Variables, and Methodology}

3.1. Data. The data used in this study mainly come from the P2P lending platform Renrendai in China. Founded in 2010, Renrendai is one of the earliest online lending information intermediary platforms in China. Either complexity of data fetching or the diversity of data makes Renrendai a great choice. In 2017, the Renrendai platform ranked second among the top 100 online lending platforms in China. Hence, empirical research based on large-scale data provided by the Renrendai platform made the research results of this study more meaningful. The Renrendai platform introduced automatic bidding service in 2014. In order to eliminate the impact of automatic bidding service, our sample consists of the order, borrower, and bid information of the Renrendai platform with an order ID ranging from 123500 to 173500 ; orders in this range occurred before the introduction of automatic bidding service. We eliminate the orders that have not received bids; at last, 11,545 orders including 494,682 bidding information are obtained, and the bid data mainly include bid time, amount, and some other information.

\subsection{Variables and Methodology. Table 1 formally defines all} of our main variables.

SEC is the time it takes for an order to receive the next bid, obtained by subtracting the time of this bid from the time of the next bid. We measure the herd behavior of investors using SEC. At present, the number of orders with a loan of more than 100,000 Yuan on the Renrendai platform has exceeded $35 \%$, and the number of bids with a high loan amount is relatively high. Therefore, we use Ln (bids), the natural logarithm of the bids received by the orders, as the independent variable. Velocity represents the average bid rate of the order, obtained by dividing the total bid time of the order by the total bid amount. We measure the degree of herd behavior using velocity. The faster the orders succeed, the more significant the investor herd behavior is. Default is a dummy variable equal to 1 if the order is default and 0 otherwise. We measure the rationality of herd behavior using default.

We follow the work of Herzenstein et al. [13] to study the influence of the number of bids received for orders on investors' herd behavior. According to the characteristics of the data in Renrendai, we measure investors' herd behavior by the time it takes for orders to be bid again. The empirical model is used to analyze whether the number of bids received for the order can significantly shorten the time needed for the order to get the bid again, so as to verify the existence of herd behavior of investors in $\mathrm{P} 2 \mathrm{P}$ online lending platforms. Our model to verify the existence of herd behavior is as follows: Control $_{i}$ includes controlling variables such as $\mathrm{BA}$, order information, and borrower information. 
TABLE 1: Variable definition.

\begin{tabular}{|c|c|c|}
\hline Main variables & & Definition \\
\hline Bid information & $\begin{array}{l}\text { SEC } \\
\text { Ln (bids) } \\
\operatorname{Ln}^{2} \text { (bids) } \\
\text { BA }\end{array}$ & $\begin{array}{l}\text { The time it takes for an order to receive the next bid, measured in seconds } \\
\text { The natural logarithm of the number of bids an order has received } \\
\text { The square of the natural logarithm of the number of bids an order has received } \\
\text { The bid amount }\end{array}$ \\
\hline Order information & $\begin{array}{l}\text { PER } \\
\text { RATE } \\
\text { Default } \\
\text { Velocity } \\
\text { Lnam } \\
\text { DUR }\end{array}$ & $\begin{array}{c}\text { Current proportion of investment received for orders } \\
\text { Interest rate of orders } \\
\text { A dummy variable equals } 1 \text { if the order is default and } 0 \text { otherwise } \\
\text { The average bid speed of the order, obtained by dividing the total bid time of the order by the total bid } \\
\text { amount } \\
\text { The natural logarithm of the amount of an order } \\
\text { Repayment term of orders }\end{array}$ \\
\hline $\begin{array}{l}\text { Borrower } \\
\text { information }\end{array}$ & $\begin{array}{l}\text { GEN } \\
\text { AGE } \\
\text { HOU } \\
\text { CRE } \\
\text { HOUSEDEBT } \\
\text { EDU }\end{array}$ & $\begin{array}{l}\text { A dummy variable equals } 1 \text { if the borrower is a man and } 0 \text { otherwise } \\
\text { The age information of the borrower ranges from } 22 \text { to } 60 \text { years } \\
\text { A dummy variable equals } 1 \text { if the borrower has a real estate and } 0 \text { otherwise } \\
\text { The borrower's credit rating, including AA, A, B, C, D, E, and HR, which are evaluated by the } \\
\text { platform } \\
\text { A dummy variable equals } 1 \text { if the borrower has a house debt and } 0 \text { otherwise } \\
\text { The borrower's education level, } 4=\text { master's degree or above; } 3 \text { = bachelor's degree; } 2=\text { college degree; } \\
\text { and } 1=\text { high-school degree or below }\end{array}$ \\
\hline
\end{tabular}

$$
\mathrm{SEC}=\beta_{0}+\beta_{1} \operatorname{Ln}(\text { bids })+\beta_{i} \operatorname{Control}_{i}+\varepsilon .
$$

In our second hypothesis, we add the square of the independent variables into our model to analyze the time required to obtain another bid based on different order bidding status in an order. Model 2 is as follows:

$$
\mathrm{SEC}=\beta_{0}+\beta_{1} \operatorname{Ln}(\text { bids })+\beta_{2} \operatorname{Ln}^{2} \text { (bids) }+\beta_{i} \operatorname{Control}_{i}+\varepsilon .
$$

To test the rationality of investors' herd behavior, we construct the logit model to study whether orders with herd behavior have a lower default rate, that is, whether investors can better identify the risks of orders by imitating the behaviors of other investors. The independent variable of this model is the average bid rate of the order, in the whole process of a bid, the dependent variable is the order default, and the control variable mainly includes the order information and the borrower information. Model 3 is as follows:

$$
\operatorname{Ln}\left[\frac{P(\text { Default }=1)}{P(\text { Default }=0)}\right]=\beta_{0}+\beta_{1} \text { Velocity }+\beta_{i} \text { Control }_{i}+\varepsilon .
$$

\section{Empirical Results}

4.1. Descriptive Statistics. Table 2 reports the mean, standard deviation, minimum, and maximum for the variables used in hypotheses 1 and 2 . The average bid amount is 1245.42 Yuan, the average loan interest rate is $12.81 \%$, and the average repayment term is 29.13 months, which is basically consistent with the characteristics of high interest rate and small loan amount in the online lending market. The highest amount order has reached 500,000 $\left(e^{13.12}\right)$ Yuan, which indicates that the development of Renrendai is a relatively
TABLE 2: Descriptive statistics of hypothesis 1 and hypothesis 2 .

\begin{tabular}{lcccc}
\hline Variable & Mean & $\begin{array}{c}\text { Standard } \\
\text { deviation }\end{array}$ & Min & Max \\
\hline Ln (bids) & 3.339 & 1.312 & 0.000 & 6.607 \\
Ln $^{2}$ (bids) & 12.873 & 8.616 & 0.000 & 43.648 \\
PER & 0.449 & 0.310 & 0.000 & 1.003 \\
BA & 1245.415 & 3301.238 & 50.000 & 200000.000 \\
RATE & 12.814 & 0.806 & 9.500 & 24.000 \\
Lnam & 11.103 & 0.569 & 8.006 & 13.122 \\
DUR & 29.128 & 9.502 & 3.000 & 36.000 \\
GEN & 0.727 & 0.445 & 0.000 & 1.000 \\
AGE & 38.921 & 8.657 & 22.000 & 65.000 \\
HOU & 0.612 & 0.487 & 0.000 & 1.000 \\
CRE & 4.902 & 0.649 & 0.000 & 6.000 \\
HOUSEDEBT & 0.456 & 0.498 & 0.000 & 1.000 \\
EDU & 1.979 & 0.711 & 1.000 & 4.000 \\
\hline
\end{tabular}

mature platform and a relatively large amount of borrowing can be accepted by investors. The average age of the borrowers is 38.92 years, $73 \%$ of the borrowers are male borrowers, $61 \%$ of the borrowers have a real estate, and $46 \%$ of the borrowers have a house debt.

The variables involved in the model are tested for multicollinearity. We use VIF to test the multicollinearity of independent variables as we test in Table 3. As shown in Table 3, the VIF value of all independent variables does not exceed 5, so there is no multicollinearity between variables. The correlation coefficient between all independent variables is also tested, and related results are shown in Table 4. According to the test results in Table 4, the correlation between the RATE and DUR is 0.73 , which conforms to the fact that the longer is the loan duration, the higher is the loan rate, so we delete DUR in our following model.

Descriptive statistics and correlation tests also were carried out for independent variables and control variables in hypothesis 3 , and the test result is shown in Table 5. There 
TABLE 3: Result of the VIF test.

\begin{tabular}{lcr}
\hline Variable & VIF & $1 /$ IF \\
\hline DUR & 3.529 & 3.529 \\
RATE & 3.061 & 3.061 \\
CRE & 1.635 & 1.635 \\
Lnbids & 1.505 & 1.505 \\
HOU & 1.394 & 1.394 \\
Lnam & 1.384 & 1.384 \\
PER & 1.329 & 1.329 \\
BA & 1.103 & 1.103 \\
AGE & 1.078 & 1.078 \\
EDU & 1.035 & 1.035 \\
GEN & 1.008 & 1.008 \\
Mean VIF & 1.642 & \\
\hline
\end{tabular}

TABLE 4: Correlation between the control variables and the main independent variables.

\begin{tabular}{|c|c|c|c|c|c|c|c|c|c|c|c|c|}
\hline & Second & Lnbids & PER & BA & RATE & Lnam & DUR & GEN & AGE & $\mathrm{HOU}$ & CRE & EDU \\
\hline Second & 1.000 & & & & & & & & & & & \\
\hline Lnbids & $\begin{array}{l}-0.036 \\
(0.000)\end{array}$ & 1.000 & & & & & & & & & & \\
\hline PER & $\begin{array}{l}-0.036 \\
(0.000) \\
\end{array}$ & $\begin{array}{c}0.404 \\
(0.000) \\
\end{array}$ & 1.000 & & & & & & & & & \\
\hline BA & $\begin{array}{l}-0.003 \\
(0.063) \\
\end{array}$ & $\begin{array}{c}-0.177 \\
(0.000) \\
\end{array}$ & $\begin{array}{c}0.116 \\
(0.000) \\
\end{array}$ & 1.000 & & & & & & & & \\
\hline RATE & $\begin{array}{l}-0.116 \\
(0.000)\end{array}$ & $\begin{array}{l}-0.027 \\
(0.000)\end{array}$ & $\begin{array}{l}-0.069 \\
(0.000)\end{array}$ & $\begin{array}{c}0.007 \\
(0.000) \\
\end{array}$ & 1.000 & & & & & & & \\
\hline Lnam & $\begin{array}{c}0.035 \\
(0.000) \\
\end{array}$ & $\begin{array}{c}0.316 \\
(0.000) \\
\end{array}$ & $\begin{array}{l}-0.004 \\
(0.014) \\
\end{array}$ & $\begin{array}{c}0.040 \\
(0.000) \\
\end{array}$ & $\begin{array}{l}-0.164 \\
(0.000) \\
\end{array}$ & 1.000 & & & & & & \\
\hline DUR & $\begin{array}{c}-0.110 \\
(0.000) \\
\end{array}$ & $\begin{array}{c}0.059 \\
(0.000) \\
\end{array}$ & $\begin{array}{c}-0.113 \\
(0.000) \\
\end{array}$ & $\begin{array}{c}0.007 \\
(0.000) \\
\end{array}$ & $\begin{array}{c}0.732 \\
(0.000) \\
\end{array}$ & $\begin{array}{c}0.030 \\
(0.000) \\
\end{array}$ & 1.000 & & & & & \\
\hline GEN & $\begin{array}{c}0.002 \\
(0.108) \\
\end{array}$ & $\begin{array}{l}-0.023 \\
(0.000)\end{array}$ & $\begin{array}{c}0.017 \\
(0.000)\end{array}$ & $\begin{array}{l}-0.001 \\
(0.313)\end{array}$ & $\begin{array}{l}-0.035 \\
(0.000)\end{array}$ & $\begin{array}{l}-0.036 \\
(0.000)\end{array}$ & $\begin{array}{l}-0.058 \\
(0.000) \\
\end{array}$ & 1.000 & & & & \\
\hline AGE & $\begin{array}{c}0.028 \\
(0.000) \\
\end{array}$ & $\begin{array}{c}0.058 \\
(0.000) \\
\end{array}$ & $\begin{array}{c}0.002 \\
(0.110) \\
\end{array}$ & $\begin{array}{c}0.006 \\
(0.000) \\
\end{array}$ & $\begin{array}{l}-0.146 \\
(0.000) \\
\end{array}$ & $\begin{array}{c}0.208 \\
(0.000) \\
\end{array}$ & $\begin{array}{l}-0.094 \\
(0.000) \\
\end{array}$ & $\begin{array}{c}0.012 \\
(0.000) \\
\end{array}$ & 1.000 & & & \\
\hline $\mathrm{HOU}$ & $\begin{array}{l}-0.066 \\
(0.000)\end{array}$ & $\begin{array}{c}0.010 \\
(0.000) \\
\end{array}$ & $\begin{array}{l}-0.043 \\
(0.000)\end{array}$ & $\begin{array}{c}0.028 \\
(0.000) \\
\end{array}$ & $\begin{array}{c}0.422 \\
(0.000)\end{array}$ & $\begin{array}{c}0.115 \\
(0.000) \\
\end{array}$ & $\begin{array}{c}0.479 \\
(0.000) \\
\end{array}$ & $\begin{array}{l}-0.060 \\
(0.000)\end{array}$ & $\begin{array}{c}0.020 \\
(0.000)\end{array}$ & 1.000 & & \\
\hline CRE & $\begin{array}{c}0.012 \\
(0.000) \\
\end{array}$ & $\begin{array}{c}0.140 \\
(0.000) \\
\end{array}$ & $\begin{array}{c}-0.071 \\
(0.000) \\
\end{array}$ & $\begin{array}{c}0.004) \\
(0.004)\end{array}$ & $\begin{array}{c}-0.124 \\
(0.000)\end{array}$ & $\begin{array}{c}0.315 \\
(0.000) \\
\end{array}$ & $\begin{array}{c}0.300 \\
(0.000) \\
\end{array}$ & $\begin{array}{c}-0.054 \\
(0.000)\end{array}$ & $\begin{array}{c}0.065 \\
(0.000) \\
\end{array}$ & $\begin{array}{c}0.030 \\
(0.000) \\
\end{array}$ & 1.000 & \\
\hline EDU & $\begin{array}{c}0.002 \\
(0.246)\end{array}$ & $\begin{array}{c}0.020) \\
(0.000)\end{array}$ & $\begin{array}{c}0.021 \\
(0.000)\end{array}$ & $\begin{array}{c}0.006 \\
(0.000)\end{array}$ & $\begin{array}{c}-0.040) \\
(0.000)\end{array}$ & $\begin{array}{c}0.093 \\
(0.000)\end{array}$ & $\begin{array}{l}-0.020 \\
(0.000)\end{array}$ & $\begin{array}{l}-0.010 \\
(0.000)\end{array}$ & $\begin{array}{l}-0.089 \\
(0.000)\end{array}$ & $\begin{array}{l}-0.077 \\
(0.000)\end{array}$ & $\begin{array}{l}-0.014 \\
(0.000)\end{array}$ & 1.000 \\
\hline
\end{tabular}

TABLE 5: Descriptive statistics and correlation tests for hypothesis 3.

\begin{tabular}{lccccccccccccc}
\hline & Mean & Standard deviation & Min & Max & Velocity & Lnam & RATE & DUR & GEN & AGE & HOU & CRE & EDU \\
\hline Velocity & 35.561 & 164.531 & 0.000 & 3862.833 & 1.000 & & & & & & & & \\
Lnam & 10.828 & 0.636 & 8.006 & 13.122 & 0.047 & 1.000 & & & & & & \\
RATE & 12.905 & 1.041 & 9.500 & 24.000 & -0.210 & -0.084 & 1.000 & & & & & \\
DUR & 28.407 & 10.122 & 3.000 & 36.000 & -0.206 & 0.418 & 0.421 & 1.000 & & & & \\
GEN & 0.737 & 0.440 & 0.000 & 1.000 & 0.012 & -0.077 & 0.001 & -0.076 & 1.000 & & & \\
AGE & 38.092 & 8.607 & 22.000 & 65.000 & 0.050 & 0.196 & -0.113 & 0.010 & -0.003 & 1.000 & & \\
HOU & 0.585 & 0.493 & 0.000 & 1.000 & -0.121 & 0.337 & 0.238 & 0.402 & -0.058 & 0.097 & 1.000 & \\
CRE & 4.723 & 1.076 & 0.000 & 6.000 & 0.049 & 0.533 & -0.274 & 0.454 & -0.077 & 0.138 & 0.080 & 1.000 & \\
EDU & 1.970 & 0.719 & 1.000 & 4.000 & -0.012 & 0.016 & -0.007 & -0.001 & -0.005 & -0.114 & -0.029 & -0.020 & 1.000 \\
\hline
\end{tabular}




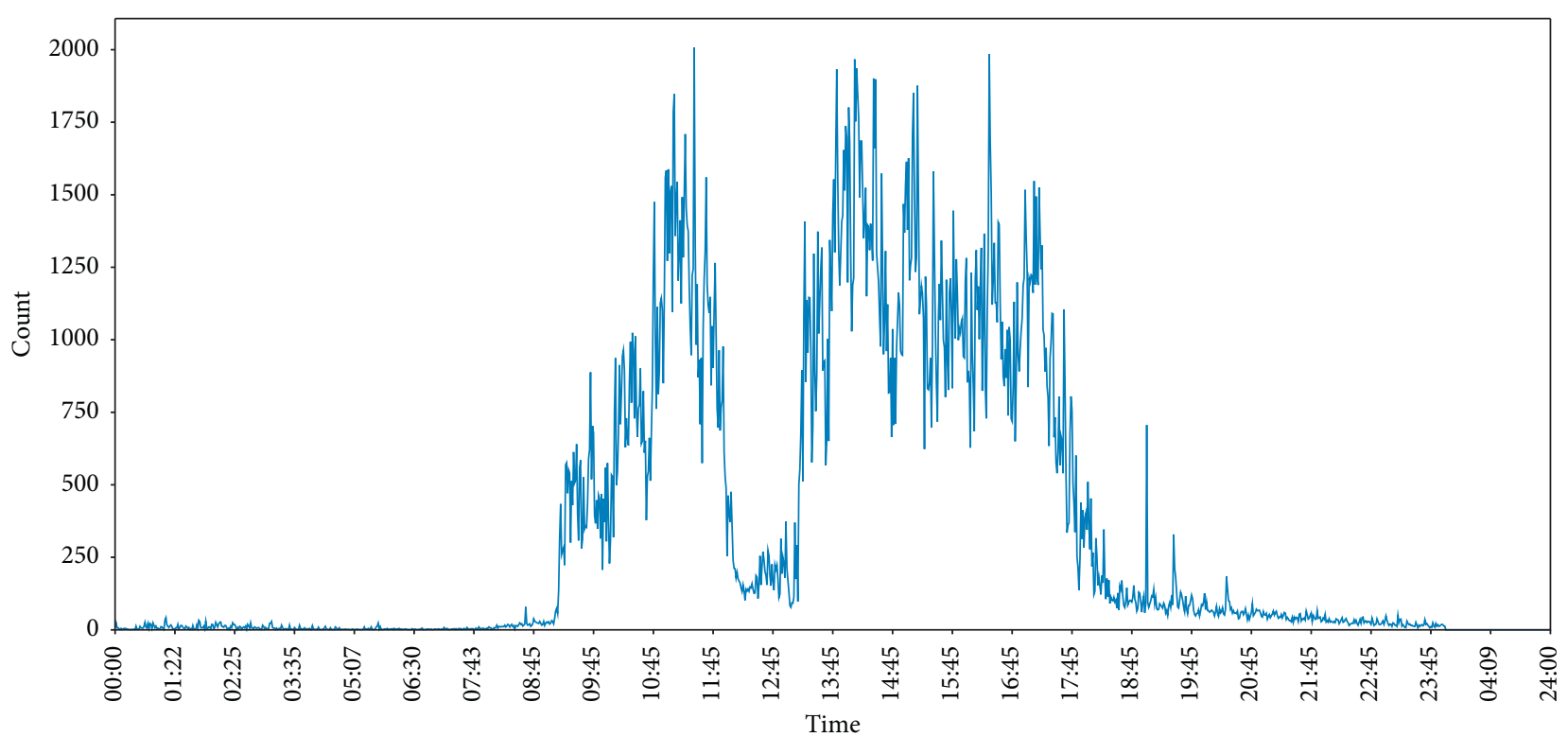

FIgURE 1: The time distribution of bid according to minutes. This figure illustrates the evolution of bid numbers measured in minute degree. The $x$-axis denotes the time, and the $y$-axis denotes its magnitude.

TABLE 6: Existence of investor herd behavior.

\begin{tabular}{|c|c|c|c|c|}
\hline \multirow{2}{*}{ Variables } & \multicolumn{2}{|c|}{ Model 1} & \multicolumn{2}{|c|}{ Model 2} \\
\hline & Model 1a & Model 1b & Model 2a & Model 2b \\
\hline Lnbids & $\begin{array}{c}-10.611 * * * \\
(\leq 0.001)\end{array}$ & $\begin{array}{c}-10.653 * * * \\
(\leq 0.001)\end{array}$ & $\begin{array}{c}-22.981 * * * \\
(\leq 0.001)\end{array}$ & $\begin{array}{c}-23.040 * * * \\
(\leq 0.001)\end{array}$ \\
\hline $\ln ^{2}$ bids & & & $\begin{array}{c}1.930 * * * \\
(\leq 0.001)\end{array}$ & $\begin{array}{c}1.933 * * * \\
(\leq 0.001)\end{array}$ \\
\hline PER & $\begin{array}{c}-33.381 * * * \\
(\leq 0.001)\end{array}$ & $\begin{array}{c}-33.201 * * * \\
(\leq 0.001)\end{array}$ & $\begin{array}{c}-31.657 * * * \\
(\leq 0.001)\end{array}$ & $\begin{array}{c}-31.473 * * * \\
(\leq 0.001)\end{array}$ \\
\hline $\mathrm{BA}$ & $\begin{array}{c}-0.001 * * * \\
(\leq 0.001)\end{array}$ & $\begin{array}{c}-0.001 * * * \\
(\leq 0.001)\end{array}$ & $\begin{array}{c}-0.001 * * * \\
(\leq 0.001)\end{array}$ & $\begin{array}{c}-0.001 * * * \\
(\leq 0.001)\end{array}$ \\
\hline RATE & $\begin{array}{c}-45.741 * * * \\
(\leq 0.001)\end{array}$ & $\begin{array}{c}-45.739 * * * \\
(\leq 0.001)\end{array}$ & $\begin{array}{c}-46.079 * * * \\
(\leq 0.001)\end{array}$ & $\begin{array}{c}-46.077 * * * \\
(\leq 0.001)\end{array}$ \\
\hline Lnam & $\begin{array}{c}22.097 * * * \\
(\leq 0.001)\end{array}$ & $\begin{array}{c}22.662 * * * \\
(\leq 0.001)\end{array}$ & $\begin{array}{c}21.588 * * * \\
(\leq 0.001)\end{array}$ & $\begin{array}{c}22.155 * * * \\
(\leq 0.001)\end{array}$ \\
\hline GEN & $\begin{array}{l}-2.166 * \\
(-0.062) \\
\end{array}$ & $\begin{array}{l}-2.222 * \\
(-0.055) \\
\end{array}$ & $\begin{array}{l}-1.993 * \\
(-0.086) \\
\end{array}$ & $\begin{array}{l}-2.050 * \\
(-0.077) \\
\end{array}$ \\
\hline AGE & $\begin{array}{c}0.379 * * * \\
(\leq 0.001)\end{array}$ & $\begin{array}{c}0.350 * * * \\
(\leq 0.001)\end{array}$ & $\begin{array}{c}0.380 * * * \\
(\leq 0.001)\end{array}$ & $\begin{array}{c}0.351 * * * \\
(\leq 0.001)\end{array}$ \\
\hline $\mathrm{HOU}$ & $\begin{array}{c}-21.188 * * * \\
(\leq 0.001)\end{array}$ & $\begin{array}{c}-21.584 * * * \\
(\leq 0.001)\end{array}$ & $\begin{array}{c}-20.703 * * * \\
(\leq 0.001)\end{array}$ & $\begin{array}{c}-21.100 * * * \\
(\leq 0.001)\end{array}$ \\
\hline CRE & $\begin{array}{c}-4.373 * * * \\
(\leq 0.001)\end{array}$ & $\begin{array}{c}-4.525 * * * \\
(\leq 0.001)\end{array}$ & $\begin{array}{c}-4.024 * * * \\
(\leq 0.001)\end{array}$ & $\begin{array}{c}-4.176 * * * \\
(\leq 0.001)\end{array}$ \\
\hline EDU & & $\begin{array}{c}-3.022 * * * \\
(\leq 0.001)\end{array}$ & & $\begin{array}{c}-3.040 * * * \\
(\leq 0.001)\end{array}$ \\
\hline Constant & $\begin{array}{c}448.556 * * * \\
(\leq 0.001)\end{array}$ & $\begin{array}{c}450.420 * * * \\
(\leq 0.001)\end{array}$ & $\begin{array}{c}472.109 * * * \\
(\leq 0.001)\end{array}$ & $\begin{array}{c}474.019 * * * \\
(\leq 0.001)\end{array}$ \\
\hline $\mathrm{N}$ & 491502 & 491502 & 491502 & 491502 \\
\hline Adjusted R-squared & 0.017 & 0.018 & 0.018 & 0.018 \\
\hline
\end{tabular}

Note: $* * *, * *$, and $*$ denote statistical significance levels at $1 \%, 5 \%$, and $10 \%$, respectively.

is no strong correlation between the variables used in model 3 , which conforms to the requirements of the empirical model for variables. Among the 11,545 loan orders selected in this model, the average loan amount is 59893.05 Yuan, the average loan interest rate is $12.905 \%$, and the average repayment term is 28.407 months, which is basically consistent 
with the characteristics of high loan interest rate and small loan in the online lending market.

4.2. Results on the Existence of Investor Herd Behavior. We started with equation (1) to explore the existence of herd behavior. Then, we ran equation (2) to study the change trend of herd behavior. Figure 1 reports the time distribution of bid number according to minutes. As is shown clearly, most transactions happened in the daytime, and the number of bids happened from 8:00 to $23: 00$ account to $99.32 \%$ of the total number. It is obvious that rare lenders bid at night. In this section, we collect the 491502 bids in the daytime.

The results of the equations mentioned above are shown in Table 6, which shows that, with the increase of the number of bids received by the order, later investors speed up the bidding speed, and the time needed for the order to get bid again is gradually shortened. In other words, there is a significant herd behavior of investors on the Renrendai online lending platform. Model 2 in Table 6 shows that, after introducing the square of the natural logarithm of the number of bids received for an order, the result still supports model 1 and verifies hypothesis 2 . The abovementioned results show that orders that have got bids need less time to get other bids, but if there are too many bids, the process may decrease. In other words, the herd behavior of investors and the number of bids orders received show an "inverted U" relationship. The decision-making process of investors is not only influenced by the number of bids orders have received but also a relatively large number of bids may decrease investors' trust. Listings with higher rates and borrowers with high credit degrees or borrowers who own houses are more attractive for lenders. Furthermore, when we introduce education degrees, results show that, for borrowers with higher education levels, herd behavior of lenders is more obvious, which means lenders trust borrowers with relatively high education degrees more.

\subsection{Results on Rational Verification of Investor Herd Behavior.} The regression result of model 3 is shown below in Table 7. The velocity of orders has no significant decrease on the borrower default rate; that is to say, the herd behavior of investors does not help investors to improve the investment efficiency and reduce the risk. In addition, listings with higher rates increase the default rate and borrowers with better credit degrees and higher education levels decrease the default rate, while whether borrowers owning houses have no influence on the default rates. Combining the conclusion from Section 4.2, when investors make decision, they pursue listings with higher rate and borrowers with high credit degree, high education level, and borrowers who own house. Although, some of the characteristics they pursue may decrease the default rate. Overall, their herd behavior cannot decrease the default rate. Therefore, the herd behavior of investors in the $\mathrm{P} 2 \mathrm{P}$ online lending market is partly rational pursuit, but it is irrational in general. It is worth noting that the house variable, which has a significant impact on the herd behavior of investors, has no significant impact on the default rate of orders, indicating that real estate cannot be
TABLE 7: Rational verification of investor herd behavior.

\begin{tabular}{|c|c|c|c|}
\hline Variables & $(1)$ & (2) & (3) \\
\hline Velocity & $\begin{array}{c}0.001 \\
(-0.701)\end{array}$ & $\begin{array}{c}0.001 \\
(-0.696)\end{array}$ & $\begin{array}{c}0.001 \\
(-0.769)\end{array}$ \\
\hline Lnam & $\begin{array}{c}0.267 \\
(-0.19) \\
\end{array}$ & $\begin{array}{c}0.266 \\
(-0.193)\end{array}$ & $\begin{array}{c}0.316 \\
(-0.131)\end{array}$ \\
\hline RATE & $\begin{array}{l}0.131 * * \\
(-0.011) \\
\end{array}$ & $\begin{array}{c}0.131 * * \\
(-0.01) \\
\end{array}$ & $\begin{array}{l}0.129 * * \\
(-0.014) \\
\end{array}$ \\
\hline DUR & $\begin{array}{c}0.083 * * * \\
(\leq 0.001)\end{array}$ & $\begin{array}{c}0.083 * * * \\
(\leq 0.001)\end{array}$ & $\begin{array}{c}0.083 * * * \\
(\leq 0.001)\end{array}$ \\
\hline GEN & $\begin{array}{c}-0.126 \\
(-0.715)\end{array}$ & $\begin{array}{c}-0.132 \\
(-0.703)\end{array}$ & $\begin{array}{c}-0.18 \\
(-0.606)\end{array}$ \\
\hline AGE & $\begin{array}{c}0.037 * \\
(-0.056)\end{array}$ & $\begin{array}{c}0.037 * \\
(-0.054)\end{array}$ & $\begin{array}{c}0.033 * \\
(-0.096)\end{array}$ \\
\hline $\mathrm{HOU}$ & $\begin{array}{c}0.004 \\
(-0.987) \\
\end{array}$ & $\begin{array}{c}-0.048 \\
(-0.871) \\
\end{array}$ & $\begin{array}{c}-0.048 \\
(-0.874) \\
\end{array}$ \\
\hline CREDIT & $\begin{array}{c}-2.264 * * * \\
(\leq 0.001)\end{array}$ & $\begin{array}{c}-2.269 * * * \\
(\leq 0.001)\end{array}$ & $\begin{array}{c}-2.261 * * * \\
(\leq 0.001)\end{array}$ \\
\hline HOUSEDEBT & & $\begin{array}{c}0.118 \\
(-0.727) \\
\end{array}$ & $\begin{array}{c}0.226 \\
(-0.511) \\
\end{array}$ \\
\hline EDU & & & $\begin{array}{c}-0.461 * * * \\
(-0.004)\end{array}$ \\
\hline Constant & $\begin{array}{c}-7.838 * * * \\
(\leq 0.001)\end{array}$ & $\begin{array}{c}-7.842 * * * \\
(\leq 0.001)\end{array}$ & $\begin{array}{c}-7.244 * * * \\
(-0.001)\end{array}$ \\
\hline $\mathrm{N}$ & 11545 & 11545 & 11545 \\
\hline Pseudo $\mathrm{R}^{2}$ & 0.609 & 0.608 & 0.616 \\
\hline
\end{tabular}

Note: $* * *, * *$, and $*$ denote statistical significance levels at $1 \%, 5 \%$, and $10 \%$, respectively.

used as a symbol of the borrower's solvency in the P2P online lending market.

\subsection{Robustness Test}

4.4.1. Adding Further Control Variables. To examine whether the herd behavior still exists after considering other factors that may affect the herd behavior of investors, we regress equations (1) and (2) on an expanded set of control variables such as income of borrowers, whether the borrowers owe house debt, and whether the borrowers own cars. CAR and HOUSEDEBT are dummy variables to measure whether borrowers have a car or owe a house debt. INCO is a variable to measure the borrower's income level ( $6=$ job income equals to 50000 Yuan or above; $5=$ job income between 20000 Yuan and 50000 Yuan; $4=$ job income between 10000 Yuan and 20000 Yuan; $3=$ job income between 5000 Yuan and 10000 Yuan; 2=job income between 2000 Yuan and 5000 Yuan; and $1=$ job income equals to 2000 Yuan or below). The results of estimation of equations (1) and (2) are reported in Table 8. Similar to the results in Table 6, we find the herd behavior still exists after adding further control variables.

4.4.2. Expanding the Samples. In this section, robustness test on our hypothesis 1 and 2 is conducted by reconsidering the analysis from Section 4.2 by including the bids that occur in the night (23:00 to the 8:00 of the next day) to our samples. 
TABLE 8: Adding further control variables for model 1 and 2.

\begin{tabular}{|c|c|c|c|c|c|c|}
\hline \multirow{2}{*}{ Variables } & \multicolumn{3}{|c|}{ Model 1} & \multicolumn{3}{|c|}{ Model 2} \\
\hline & Model 1a & Model 1b & Model 1c & Model 2a & Model 2b & Model 2c \\
\hline Lnbids & $\begin{array}{c}-10.677 * * * \\
(\leq 0.001) \\
\end{array}$ & $\begin{array}{c}-10.676 * * * \\
(\leq 0.001)\end{array}$ & $\begin{array}{c}-10.687 * * * \\
(\leq 0.001) \\
\end{array}$ & $\begin{array}{c}-23.079 * * * \\
(\leq 0.001)\end{array}$ & $\begin{array}{c}-23.140 * * * \\
(\leq 0.001) \\
\end{array}$ & $\begin{array}{c}-23.257 * * * * \\
(\leq 0.001) \\
\end{array}$ \\
\hline $\operatorname{Ln}^{2}$ bids & & & & $\begin{array}{c}1.935 * * * \\
(\leq 0.001)\end{array}$ & $\begin{array}{c}1.945 * * * \\
(\leq 0.001)\end{array}$ & $\begin{array}{c}1.962 * * * \\
(\leq 0.001)\end{array}$ \\
\hline PER & $\begin{array}{c}-33.076 * * * \\
(\leq 0.001)\end{array}$ & $\begin{array}{c}-33.063 * * * \\
(\leq 0.001)\end{array}$ & $\begin{array}{c}-33.018 * * * \\
(\leq 0.001)\end{array}$ & $\begin{array}{c}-31.346 * * * \\
(\leq 0.001)\end{array}$ & $\begin{array}{c}-31.323 * * * \\
(\leq 0.001)\end{array}$ & $\begin{array}{c}-31.263 * * * \\
(\leq 0.001)\end{array}$ \\
\hline $\mathrm{BA}$ & $\begin{array}{c}-0.001 * * * \\
(\leq 0.001)\end{array}$ & $\begin{array}{c}-0.001 * * * \\
(\leq 0.001)\end{array}$ & $\begin{array}{c}-0.001 * * * \\
(\leq 0.001)\end{array}$ & $\begin{array}{c}-0.001 * * * \\
(\leq 0.001)\end{array}$ & $\begin{array}{c}-0.001 * * * \\
(\leq 0.001)\end{array}$ & $\begin{array}{c}-0.001 * * * \\
(\leq 0.001)\end{array}$ \\
\hline RATE & $\begin{array}{c}-45.501 * * * \\
(\leq 0.001)\end{array}$ & $\begin{array}{c}-45.524 * * * \\
(\leq 0.001)\end{array}$ & $\begin{array}{c}-45.450 * * * \\
(\leq 0.001)\end{array}$ & $\begin{array}{c}-45.839 * * * \\
(\leq 0.001)\end{array}$ & $\begin{array}{c}-45.865 * * * \\
(\leq 0.001)\end{array}$ & $\begin{array}{c}-45.792 * * * \\
(\leq 0.001)\end{array}$ \\
\hline Lnam & $\begin{array}{c}23.170 * * * \\
(\leq 0.001)\end{array}$ & $\begin{array}{c}23.079 * * * \\
(\leq 0.001)\end{array}$ & $\begin{array}{c}21.383 * * * \\
(\leq 0.001)\end{array}$ & $\begin{array}{c}22.665 * * * \\
(\leq 0.001)\end{array}$ & $\begin{array}{c}22.568 * * * \\
(\leq 0.001)\end{array}$ & $\begin{array}{c}20.821 * * * \\
(\leq 0.001)\end{array}$ \\
\hline GEN & $\begin{array}{c}-2.411 * * \\
(-0.038) \\
\end{array}$ & $\begin{array}{c}-2.719 * * \\
(-0.019) \\
\end{array}$ & $\begin{array}{c}-2.603 * * \\
(-0.025) \\
\end{array}$ & $\begin{array}{l}-2.239 * \\
(-0.054) \\
\end{array}$ & $\begin{array}{c}-2.555 * * \\
(-0.028) \\
\end{array}$ & $\begin{array}{r}-2.435 * * \\
(-0.036) \\
\end{array}$ \\
\hline AGE & $\begin{array}{c}0.305 * * * \\
(\leq 0.001)\end{array}$ & $\begin{array}{c}0.300 * * * \\
(\leq 0.001)\end{array}$ & $\begin{array}{c}0.278 * * * \\
(\leq 0.001)\end{array}$ & $\begin{array}{c}0.305 * * * \\
(\leq 0.001)\end{array}$ & $\begin{array}{c}0.301 * * * \\
(\leq 0.001)\end{array}$ & $\begin{array}{c}0.278 * * * \\
(\leq 0.001)\end{array}$ \\
\hline $\mathrm{HOU}$ & $\begin{array}{c}-16.847 * * * \\
(\leq 0.001)\end{array}$ & $\begin{array}{c}-17.691 * * * \\
(\leq 0.001)\end{array}$ & $\begin{array}{c}-18.548 * * * \\
(\leq 0.001)\end{array}$ & $\begin{array}{c}-16.342 * * * \\
(\leq 0.001)\end{array}$ & $\begin{array}{c}-17.209 * * * \\
(\leq 0.001)\end{array}$ & $\begin{array}{c}-18.085 * * * \\
(\leq 0.001)\end{array}$ \\
\hline CRE & $\begin{array}{c}-4.329 * * * \\
(\leq 0.001)\end{array}$ & $\begin{array}{c}-4.211 * * * \\
(\leq 0.001)\end{array}$ & $\begin{array}{c}-3.691 * * * \\
(\leq 0.001)\end{array}$ & $\begin{array}{c}-3.979 * * * \\
(\leq 0.001)\end{array}$ & $\begin{array}{c}-3.855 * * * \\
(\leq 0.001)\end{array}$ & $\begin{array}{c}-3.318 * * * \\
(\leq 0.001)\end{array}$ \\
\hline EDU & $\begin{array}{c}-3.002 * * * \\
(\leq 0.001)\end{array}$ & $\begin{array}{c}-2.993 * * * \\
(\leq 0.001)\end{array}$ & $\begin{array}{c}-3.121 * * * \\
(\leq 0.001)\end{array}$ & $\begin{array}{c}-3.020 * * * \\
(\leq 0.001)\end{array}$ & $\begin{array}{c}-3.012 * * * \\
(\leq 0.001)\end{array}$ & $\begin{array}{c}-3.143 * * * \\
(\leq 0.001)\end{array}$ \\
\hline HOUSEDEBT & $\begin{array}{c}-6.675 * * * \\
(\leq 0.001)\end{array}$ & $\begin{array}{c}-6.516 * * * \\
(\leq 0.001)\end{array}$ & $\begin{array}{c}-7.506 * * * \\
(\leq 0.001)\end{array}$ & $\begin{array}{c}-6.704 * * * \\
(\leq 0.001)\end{array}$ & $\begin{array}{c}-6.541 * * * \\
(\leq 0.001)\end{array}$ & $\begin{array}{c}-7.559 * * * \\
(\leq 0.001)\end{array}$ \\
\hline CAR & & $\begin{array}{c}4.100 * * * \\
(-0.001)\end{array}$ & $\begin{array}{r}2.533 * * \\
(-0.041)\end{array}$ & & $\begin{array}{c}4.223 * * * \\
(\leq 0.001)\end{array}$ & $\begin{array}{l}2.614 * * \\
(-0.035)\end{array}$ \\
\hline INCO & & & $\begin{array}{c}2.225 * * * \\
(\leq 0.001)\end{array}$ & & & $\begin{array}{c}2.286 * * * \\
(\leq 0.001)\end{array}$ \\
\hline Constant & $\begin{array}{c}442.821 * * * \\
(\leq 0.001)\end{array}$ & $\begin{array}{c}443.279 * * * \\
(\leq 0.001)\end{array}$ & $\begin{array}{c}452.218 * * * \\
(\leq 0.001)\end{array}$ & $\begin{array}{c}466.414 * * * \\
(\leq 0.001)\end{array}$ & $\begin{array}{c}467.004 * * * \\
(\leq 0.001) \\
\end{array}$ & $\begin{array}{c}476.390 * * * \\
(\leq 0.001)\end{array}$ \\
\hline $\mathrm{N}$ & 491502 & 491502 & 491502 & 491502 & 491502 & 491502 \\
\hline Adjusted R-squared & 0.018 & 0.018 & 0.018 & 0.018 & 0.018 & 0.018 \\
\hline
\end{tabular}

Note: $* * *, * *$, and $*$ denote statistical significance levels at $1 \%, 5 \%$, and $10 \%$, respectively.

TABLE 9: Expanding the bids occurred at night.

\begin{tabular}{|c|c|c|c|c|}
\hline \multirow{2}{*}{ Variables } & \multicolumn{2}{|c|}{ Model 1} & \multicolumn{2}{|c|}{ Model 2} \\
\hline & Model 1a & Model 1b & Model 2a & Model 2b \\
\hline Lnbids & $\begin{array}{c}-9.554 * * * \\
(\leq 0.001)\end{array}$ & $\begin{array}{c}-9.605 * * * \\
(\leq 0.001)\end{array}$ & $\begin{array}{c}-16.008 * * * \\
(\leq 0.001)\end{array}$ & $\begin{array}{c}-16.080 * * * \\
(\leq 0.001)\end{array}$ \\
\hline $\ln ^{2}$ bids & & & $\begin{array}{c}1.007 * * * \\
-0.002 \\
\end{array}$ & $\begin{array}{c}1.010 * * * \\
-0.002\end{array}$ \\
\hline PER & $\begin{array}{c}-47.040 * * * \\
(\leq 0.001)\end{array}$ & $\begin{array}{c}-46.823 * * * \\
(\leq 0.001)\end{array}$ & $\begin{array}{c}-46.156 * * * \\
(\leq 0.001)\end{array}$ & $\begin{array}{c}-45.936 * * * \\
(\leq 0.001)\end{array}$ \\
\hline BA & $\begin{array}{c}-0.001 * * * \\
(\leq 0.001)\end{array}$ & $\begin{array}{c}-0.001 * * * \\
(\leq 0.001)\end{array}$ & $\begin{array}{c}-0.001 * * * \\
(\leq 0.001)\end{array}$ & $\begin{array}{c}-0.001 * * * \\
(\leq 0.001)\end{array}$ \\
\hline RATE & $\begin{array}{c}-58.092 * * * \\
(\leq 0.001)\end{array}$ & $\begin{array}{c}-58.088 * * * \\
(\leq 0.001)\end{array}$ & $\begin{array}{c}-58.274 * * * \\
(\leq 0.001)\end{array}$ & $\begin{array}{c}-58.271 * * * \\
(\leq 0.001)\end{array}$ \\
\hline Lnam & $\begin{array}{c}29.646 * * * \\
(\leq 0.001)\end{array}$ & $\begin{array}{c}30.319 * * * \\
(\leq 0.001)\end{array}$ & $\begin{array}{c}29.374 * * * \\
(\leq 0.001)\end{array}$ & $\begin{array}{c}30.048 * * * \\
(\leq 0.001)\end{array}$ \\
\hline GEN & $\begin{array}{c}-1.408 \\
(-0.385)\end{array}$ & $\begin{array}{c}-1.475 \\
(-0.363) \\
\end{array}$ & $\begin{array}{c}-1.316 \\
(-0.417)\end{array}$ & $\begin{array}{c}-1.383 \\
(-0.394) \\
\end{array}$ \\
\hline
\end{tabular}


TABle 9: Continued.

\begin{tabular}{|c|c|c|c|c|}
\hline \multirow{2}{*}{ Variables } & \multicolumn{2}{|c|}{ Model 1} & \multicolumn{2}{|c|}{ Model 2} \\
\hline & Model 1a & Model $1 \mathrm{~b}$ & Model 2a & Model 2b \\
\hline AGE & $\begin{array}{c}0.541 * * * \\
(\leq 0.001)\end{array}$ & $\begin{array}{c}0.508 * * * \\
(\leq 0.001)\end{array}$ & $\begin{array}{c}0.542 * * * \\
(\leq 0.001)\end{array}$ & $\begin{array}{c}0.508 * * * \\
(\leq 0.001)\end{array}$ \\
\hline $\mathrm{HOU}$ & $\begin{array}{c}-25.011 * * * \\
(\leq 0.001)\end{array}$ & $\begin{array}{c}-25.479 * * * \\
(\leq 0.001)\end{array}$ & $\begin{array}{c}-24.754 * * * \\
(\leq 0.001)\end{array}$ & $\begin{array}{c}-25.223 * * * \\
(\leq 0.001)\end{array}$ \\
\hline CRE & $\begin{array}{c}-7.009 * * * \\
(\leq 0.001)\end{array}$ & $\begin{array}{c}-7.190 * * * \\
(\leq 0.001)\end{array}$ & $\begin{array}{c}-6.826 * * * \\
(\leq 0.001)\end{array}$ & $\begin{array}{c}-7.006 * * * \\
(\leq 0.001)\end{array}$ \\
\hline EDU & & $\begin{array}{c}-3.597 * * * \\
(\leq 0.001)\end{array}$ & & $\begin{array}{c}-3.607 * * * \\
(\leq 0.001)\end{array}$ \\
\hline Constant & $\begin{array}{c}543.391 * * * \\
(\leq 0.001)\end{array}$ & $\begin{array}{c}545.576 * * * \\
(\leq 0.001)\end{array}$ & $\begin{array}{c}555.828 * * * \\
(\leq 0.001)\end{array}$ & $\begin{array}{c}558.060 * * * \\
(\leq 0.001)\end{array}$ \\
\hline $\mathrm{N}$ & 494854 & 494854 & 494854 & 494854 \\
\hline Adjusted R-squared & 0.014 & 0.014 & 0.014 & 0.014 \\
\hline
\end{tabular}

Note: $* * *, * *$, and $*$ denote statistical significance levels at $1 \%, 5 \%$, and $10 \%$, respectively.

TABLE 10: Using alternative dependent variable and independent variable.

\begin{tabular}{|c|c|c|c|c|}
\hline & $\mathrm{BA}$ & $\mathrm{BA}$ & BA & $\mathrm{BA}$ \\
\hline Bids & $\begin{array}{c}-4.847 * * * \\
(\leq 0.001)\end{array}$ & $\begin{array}{c}-6.206 * * * \\
(\leq 0.001)\end{array}$ & $\begin{array}{c}-11.468 * * * \\
(\leq 0.001)\end{array}$ & $\begin{array}{c}-14.016 * * * \\
(\leq 0.001)\end{array}$ \\
\hline Cum & & $\begin{array}{c}0.007 * * * \\
(\leq 0.001)\end{array}$ & & $\begin{array}{c}0.008 * * * \\
(\leq 0.001)\end{array}$ \\
\hline $\mathrm{Bids}^{2}$ & & & $\begin{array}{c}0.019 * * * \\
(\leq 0.001)\end{array}$ & $\begin{array}{c}0.021 * * * \\
(\leq 0.001)\end{array}$ \\
\hline RATE & $\begin{array}{c}-15.332 * * \\
(-0.017) \\
\end{array}$ & $\begin{array}{c}54.121 * * * \\
(\leq 0.001)\end{array}$ & $\begin{array}{c}-18.486 * * * \\
(-0.004)\end{array}$ & $\begin{array}{c}62.783 * * * \\
(\leq 0.001)\end{array}$ \\
\hline GEN & $\begin{array}{c}-23.121 * * \\
(-0.023)\end{array}$ & $\begin{array}{c}-29.457 * * * \\
(-0.004)\end{array}$ & $\begin{array}{c}-18.482 * \\
(-0.069)\end{array}$ & $\begin{array}{c}-25.272 * * \\
(-0.013)\end{array}$ \\
\hline AGE & $\begin{array}{c}3.936 * * * \\
(\leq 0.001)\end{array}$ & $\begin{array}{c}0.748 \\
(-0.163) \\
\end{array}$ & $\begin{array}{c}5.021 * * * \\
(\leq 0.001)\end{array}$ & $\begin{array}{c}1.426 * * * \\
(-0.008)\end{array}$ \\
\hline $\mathrm{HOU}$ & $\begin{array}{c}202.361 * * * \\
(\leq 0.001)\end{array}$ & $\begin{array}{c}207.980 * * * \\
(\leq 0.001)\end{array}$ & $\begin{array}{c}187.658 * * * \\
(\leq 0.001)\end{array}$ & $\begin{array}{c}192.159 * * * \\
(\leq 0.001)\end{array}$ \\
\hline CRE & $\begin{array}{c}68.253 * * * \\
(\leq 0.001)\end{array}$ & $\begin{array}{c}67.464 * * * \\
(\leq 0.001)\end{array}$ & $\begin{array}{c}96.594 * * * \\
(\leq 0.001)\end{array}$ & $\begin{array}{c}99.732 * * * \\
(\leq 0.001)\end{array}$ \\
\hline EDU & $\begin{array}{c}49.256 * * * \\
(\leq 0.001)\end{array}$ & $\begin{array}{c}19.182 * * * \\
(-0.003)\end{array}$ & $\begin{array}{c}57.611 * * * \\
(\leq 0.001)\end{array}$ & $\begin{array}{c}23.423 * * * \\
(\leq 0.001)\end{array}$ \\
\hline Constant & $\begin{array}{c}995.712 * * * \\
(\leq 0.001)\end{array}$ & $\begin{array}{l}140.726 \\
(-0.157) \\
\end{array}$ & $\begin{array}{c}1049.379 * * * \\
(\leq 0.001)\end{array}$ & $\begin{array}{c}51.063 \\
(-0.606) \\
\end{array}$ \\
\hline $\mathrm{N}$ & 483770 & 483770 & 483770 & 483770 \\
\hline Adjusted R-squared & 0.016 & 0.022 & 0.023 & 0.029 \\
\hline
\end{tabular}

Note: $* * *, * *$, and $*$ denote statistical significance levels at $1 \%, 5 \%$, and $10 \%$, respectively.

The results are reported in Table 9, and the results still support our hypothesis 1 and 2 that investors on the Renrendai platform showed a significant herd behavior and there is an "inverted U-shaped" relationship between herd behavior and the number of bids orders have received.

4.4.3. Using an Alternative Dependent Variable and Independent Variable. We also reestimate our model by using alternative dependent variables to measure the herd behavior. As to the independent variables, we add the cumulated bid amount as our main independent. As shown in Table 10, with the increase of cumulated bid amount, investors increase their bid amount, while with the increase of the number of bids an order has received, investors decrease their bid amount. It is reasonable. Other things being equal, the more bids an order has got, the less the average amount of bids would be and lenders may believe other investors do not trust the orders. These results also support our hypothesis that herd behavior exist in Chinese P2P Online Lending Markets.

4.4.4. Robustness Test for Hypothesis 3. In this section, the robustness test on our hypothesis 3 is conducted by reconsidering the analysis from Section 4.3 by introducing 
TABLE 11: Robustness test for hypothesis 3.

\begin{tabular}{|c|c|c|c|}
\hline Variables & $(1)$ & $(2)$ & (3) \\
\hline Velocity & $\begin{array}{c}0.001 \\
(-0.705) \\
\end{array}$ & $\begin{array}{c}0.001 \\
(-0.7) \\
\end{array}$ & $\begin{array}{c}0.001 \\
(-0.768) \\
\end{array}$ \\
\hline Lnam & $\begin{array}{c}0.164 \\
(-0.471)\end{array}$ & $\begin{array}{c}0.164 \\
(-0.471)\end{array}$ & $\begin{array}{c}0.23 \\
(-0.328)\end{array}$ \\
\hline RATE & $\begin{array}{c}0.136 * * * \\
(-0.009)\end{array}$ & $\begin{array}{c}0.136 * * * \\
(-0.008)\end{array}$ & $\begin{array}{l}0.133 * * \\
(-0.011)\end{array}$ \\
\hline DUR & $\begin{array}{c}0.089 * * * \\
(\leq 0.001)\end{array}$ & $\begin{array}{c}0.089 * * * \\
(\leq 0.001)\end{array}$ & $\begin{array}{c}0.088 * * * \\
(\leq 0.001)\end{array}$ \\
\hline GEN & $\begin{array}{c}-0.133 \\
(-0.701)\end{array}$ & $\begin{array}{l}-0.138 \\
(-0.69)\end{array}$ & $\begin{array}{c}-0.18 \\
(-0.607) \\
\end{array}$ \\
\hline AGE & $\begin{array}{c}0.034 * \\
(-0.083)\end{array}$ & $\begin{array}{l}0.034 * \\
(-0.08)\end{array}$ & $\begin{array}{c}0.031 \\
(-0.124)\end{array}$ \\
\hline $\mathrm{HOU}$ & $\begin{array}{c}0.005 \\
(-0.984)\end{array}$ & $\begin{array}{c}-0.043 \\
(-0.884)\end{array}$ & $\begin{array}{l}-0.046 \\
(-0.88)\end{array}$ \\
\hline CREDIT & $\begin{array}{c}-2.269 * * * \\
(\leq 0.001)\end{array}$ & $\begin{array}{c}-2.273 * * * \\
(\leq 0.001)\end{array}$ & $\begin{array}{c}-2.264 * * * \\
(\leq 0.001)\end{array}$ \\
\hline INCO & $\begin{array}{c}0.107 \\
(-0.307) \\
\end{array}$ & $\begin{array}{c}0.106 \\
(-0.312) \\
\end{array}$ & $\begin{array}{c}0.085 \\
(-0.427) \\
\end{array}$ \\
\hline HOUSEDEBT & & $\begin{array}{c}0.109 \\
(-0.748)\end{array}$ & $\begin{array}{c}0.213 \\
(-0.536)\end{array}$ \\
\hline EDU & & & $\begin{array}{c}-0.452 * * * \\
(-0.004)\end{array}$ \\
\hline Constant & $\begin{array}{c}-7.259 * * * \\
(-0.001)\end{array}$ & $\begin{array}{c}-7.269 * * * \\
(-0.001)\end{array}$ & $\begin{array}{c}-6.782 * * * \\
(-0.002) \\
\end{array}$ \\
\hline $\mathrm{N}$ & 11545 & 11545 & 11545 \\
\hline Pseudo $\mathrm{R}^{2}$ & 0.610 & 0.609 & 0.617 \\
\hline
\end{tabular}

Note: $* * *, * *$, and $*$ denote statistical significance levels at $1 \%, 5 \%$, and $10 \%$, respectively.

INCO (the definition of INCO is the same as in 4.4.1) as the control variable. As shown in Table 11, we find the herd behavior of investors in the $\mathrm{P} 2 \mathrm{P}$ online lending market is the blind pursuit behavior after adding further control variables, which is similar compared to the results in Table 7.

\section{Conclusions}

The primary aim of this study is to investigate the existence of herd behavior in Chinese online lending market Renrendai and whether the herd behavior is rational. Specifically, we conduct an empirical test and come to the following conclusions:

Firstly, there is a significant herd behavior of investors on the Renrendai online lending platform, which is consistent with studies of other scholars. Secondly, there is an "inverted U-shaped" relationship between investor herd behavior and the number of bids. With the increase of the number of bids, the time required for the order to be bid again increases, and investor herd behavior decreases. Thirdly, we get the conclusion that the herd behavior in Renrendai is partly rational, but is irrational in general. This is different from the results of American online lending platform Prosper. Furthermore, our study includes real estate and real estate debt as control variables, which is of great significant for herd behavior. In a Chinese traditional view, house is a symbol of wealth, and house may represent the repayment ability of borrowers. In this study, it is proven investors' herd behavior is more likely to occur in the listings of borrowers who own a property, while our study also proves it is irrational to pursue the "house-owner-borrowers."

\section{Data Availability}

The data used to support the findings of this study are available from the corresponding author upon request.

\section{Conflicts of Interest}

The authors declare no conflicts of interest.

\section{Acknowledgments}

This work was supported by the National Natural Science Foundation of China (Grant nos. 71790594, 71661137001, and 71532009).

\section{References}

[1] "The $44^{\text {th }}$ China statistical report on internet development," 2019, http://www.cac.gov.cn/2019-08/30/c_1124938750. htm,\%202019-08-30.

[2] S. Freedman and G. Z. Jin, "Do social networks solve information problems for peer-to-peer lending? evidence from prosper.com," SSRN Electronic Journal, 2008.

[3] A. V. Banerjee, "A simple model of herd behavior," The Quarterly Journal of Economics, vol. 107, no. 3, pp. 797-817, 1992.

[4] R. Shiller, "Conversation, information, and herd behavior," American Economic Review, vol. 85, pp. 181-185, 1995.

[5] A. P. Zemsky, "Multidimensional uncertainty and herd behavior in financial markets," The American Economic Review, vol. 88, no. 3, pp. 724-748, 1998.

[6] S. Bikhchandani and S. Sharma, "Herd behavior in financial markets," IMF Staff Papers, vol. 47, no. 3, 2001.

[7] J. C. Yang, Y. C. Ho, X. Yan, and Y. Tan, "Investor platform choice: herding, platform attributes, and regulations," Journal of Management Information Systems, vol. 35, pp. 86-116, 2018.

[8] Y. Zhao, W. Zhang, P. Wang, and D. Shen, "Borrower platform choice: the influencing factors on herding," International Journal of Financial Engineering, vol. 7, no. 1, Article ID 2050002, 2020.

[9] X. Xiong, C. Wang, and D. Shen, "Market participation willingness and investor's herding behavior: evidence from an emerging market," Asia-Pacific Financial Markets, vol. 27, 2020.

[10] A. Shleifer and L. H. Summers, "The noise trader approach to finance," Journal of Economic Perspectives, vol. 4, no. 2, pp. 19-33, 1990.

[11] G. Elison and D. Fudenberg, "Rules of thumb for social learning," Journal of Political Economy, vol. 101, 1993.

[12] K. A. Krumme and S. Herrero, "Lending behavior and community structure in an online peer-to-peer economic network," in Proceedings of the 2009 International Conference on Computational Science and Engineering, Vancouver, Canada, August 2009.

[13] M. Herzenstein, U. M. Dholakia, R. L. Andrews et al., "Strategic herding behavior in peer-to-peer loan auctions," 
Journal of Interactive Marketing, vol. 25, no. 1, pp. 27-36, 1990.

[14] E. Berkovich, "Search and herding effects in peer-to-peer lending: evidence from prosper.com," Annals of Finance, vol. 7, no. 3, pp. 389-405, 2011.

[15] E. Lee and B. Lee, "Herding behavior in online P2P lending: an empirical investigation," Electronic Commerce Research and Applications, vol. 11, no. 5, pp. 495-503, 2012.

[16] H. Yum, B. Lee, and M. Chae, "From the wisdom of crowds to my own judgment in microfinance through online peer-topeer lending platforms," Electronic Commerce Research and Applications, vol. 11, no. 5, pp. 469-483, 2012.

[17] L. Liao, M. R. Li, Z. W. Wang et al., "Learning by observing: information discovery and herding behavior in P2P lending market," Journal of Tsinghua University (Philosophy and Social Sciences), vol. 1, pp. 156-165, 2015.

[18] X. G. Li and Y. F. Liu, "Study on the formation mechanism for P2P herding effect in China and the countermeasures," Cedit Reference, vol. 33, no. 12, pp. 64-68, 2015.

[19] Y. L. Li, Y. Guo, and W. Zhang, "The analysis of impact factors on loan performance in Chinese P2P Microfinance market," Journal of Finance Research, vol. 7, pp. 126-138, 2013.

[20] Y. B. Lv, Y. W. Jiang, and X. Q. Zhang, "Research on overdue behavior and herd behavior of $\mathrm{P} 2 \mathrm{P}$ platform online lending in China," Statistic and Decision, vol. 4, p. 162, 2016.

[21] J. Zhang and P. Liu, "Rational herding in microloan markets"” Management Science, vol. 58, no. 5, pp. 64-68, 2012.

[22] B. Luo and Z. Lin, "A decision tree model for herd behavior and empirical evidence from the online P2P lending market," Information Systems and E-Business Management, vol. 11, no. 1, pp. 141-160, 2013.

[23] D. Chen and Z. Lin, "Rational or irrational herding in online microloan markets: evidence from China," Social Science Electronic Publishing, 2014.

[24] J. H. Zeng and S. Yang, "Herding behavior of lenders in P2P lending markets and its rational test: evidence from PaiPaiDai market," Modern Finance and Economics, vol. 7, pp. 22-32, 2014. 